Jurnal Agrotech 9 (2) 66-71

e-ISSN : 2621-7236

p-ISSN : 1858-134X

\title{
EFEKTIVITAS EKSTRAK DAUN NIMBA (Azadirachta indica A. Juss) DALAM MENGATASI SERANGAN LIRIOMYZA SPP PADA TANAMAN BAWANG MERAH LEMBAH PALU
}

\section{THE EFFECTIVENESS OF NEEM LEAF EXTRACT (Azadirachta indica A. JUSS) IN OVERCOMING OF ATTACK LIRIOMYZA SPP ON SHALLOT LEMBAH PALU VARIETY}

\author{
$\operatorname{Arfan}^{1^{*}}$, Ratnawati $^{1}$, Hasmari $^{1}$, Lisa Indriani $^{1}$ Asli $^{2}$, Juhana $^{3}$ \\ ${ }^{1}$ Fakultas Pertanian Universitas Alkhairaat Universitas Alkhairaat, \\ Jl. Diponegoro, Palu 94221, Indonesia \\ ${ }^{2}$ UPT PTPH Sigi \\ ${ }^{3}$ Penyuluh Pertanian Tanaman Pangan dan Hortikultura Kota Palu
}

\begin{abstract}
ABSTRAK
Penelitian ini bertujuan untuk mengkaji efektivitas berbagai konsentrasi ekstrak daun nimba terhadap intensitas serangan Liriomyza spp pada tanaman bawang merah lembah Palu, yang dilakukan di Desa Guntarano Kecamatan Tanantovea Kabupaten Donggala. Penelitian dilaksanakan mulai Februari hingga April 2016. Penelitian ini menggunakan Rancangan Acak Kelompok (RAK) dengan 3 ulangan, terdiri 6 perlakuan. Yaitu P0 : Kontrol ( tanpa aplikasi ekstrak nimba ); P1 : Ekstrak daun nimba 10 gr /liter; P2 : Ekstrak daun nimba 20 gr /liter; P3 : Ekstrak daun nimba 30 gr /liter; P4 : Ekstrak daun nimba 40 gr /liter; P5 : Ekstrak daun nimba 50 gr /liter. Untuk mengetahui pengaruh perlakuan, maka dilakukan analisis ragam dan bila berpengaruh nyata dilanjutkan dengan taraf uji BNTó $=0.05$. Hasil penelitian menunjukkan bahwa perlakuan ekstrak daun nimba sebesar 50 gr/liter (P5) bisa mengendalikan serangan Liriomyza spp, tingkat serangan hanya sebesar 3,04 persen dan produksi tanaman bawang merah Lembah Palu sebesar 3,02 kg/petak.
\end{abstract}

Kata kunci: Efektivitas, Nimba, Liriomyza, Bawang Merah Lokal Palu.

\section{ABSTRACT}

The purposes of this research the examine the effectiveness various concentrations neem leaf ekstract on the intensity of attack Liriomyza spp on shallot Lembah Palu variety. Field research was carried out in Guntarano Village, Tanantovea Subdistrict, Donggala Regency, Central Sulawesi. This research conducted from February to April 2016 . The experiment was done using Randomized Complete Block Design with three replications, consists of six treatments, i.e. PO : control (without aplication neem leaf ekstract); P1: neem leaf ekstract $10 \mathrm{gr} /$ litre; P2 : neem leaf ekstract $20 \mathrm{gr} /$ litre; P3 : neem leaf ekstract $30 \mathrm{gr} /$ litre; P4 : neem leaf ekstract $40 \mathrm{gr} /$ litre; P5 : neem leaf ekstract $50 \mathrm{gr} /$ litre. To find out the effect of threatment, the analysis of variance, and the real influence is continued with the standard $\dot{\alpha}=$ 0.05 BNT test. The results showed that use of seed and leaf extracts of neem plant can control Liriomyza spp attack, only 3,04 percent of attack rate and shallot Lembah Palu variety productivity is 3,02/area.

Key words: Effectiveness, Neem, Liriomyza, shallot Lembah Palu variety.

\section{Pendahuluan}

Tanaman bawang merah lokal Palu (Allium cepa L.x Wakegi Araki) merupakan komoditi andalan dengan luas panen mencapai $1.221 \mathrm{Ha}$,

\footnotetext{
${ }^{*}$ Penulis Korespondensi.

E-mail: arfanilmu@gmail.com

Telp: +62-85228976417
}

produksi 8.659 ton atau rata-rata 7,09 ton per hektar pertahun. Desa Guntarano sebagai salah satu sentra produksi bawang merah lembah Palu memiliki Luas Panen sebesar $83 \mathrm{Ha}$, rata rata produksi hanya mencapai 4,5 ton/ha (Data Desa Guntarano, 2015), dan jika melihat potensi produksi bawang merah maka hasil tersebut masih tergolong rendah karena potensi hasil 
Jurnal Agrotech 9 (2) 66-71

bawang merah secara umum dapat mencapai 10 ton/ha (Maskar $d k k, 1999)$.

Serangan serangga herbivora lalat pengorok daun (Liriomyzaspp) disinyalir sebagai salah satu penyebab utama menurunnya produksi (Shahabuddin, dkk., 2012). Serangga herbivora ini tergolong baru keberadaannya di Sulawesi Tengah, sejak tahun 2005 mulai menyerang pertanaman Bawang merah di Lembah Palu (Anshari, 2010; Nonci, 2010; Shahabuddin, 2014), sebagai hama sekunder namun sekarang telah berkembang menjadi hama utama, bahkan serangannya menyebabkan menurunnya produksi bawang merah akibat serangan lalat penggorok daun ini (Shahabuddin, dkk., 2013. Luas serangan Liriomyza spp. 15 Ha (kategori ringan), $17 \mathrm{Ha}$ (kategori sedang), $12 \mathrm{Ha}$ (kategori berat) yang menyebabkan pertanaman bawang merah seluas $34 \mathrm{Ha}$ yang ada di Lembah Palu mengalami puso atau gagal panen(UPT PTPH, 2010).

Umumnya petani dalam mengatasi serangan hama Liriomyza spp dengan menggunakan insektisida kimia (Shahabuddin, 2014). Selain itu, hama Liriomyza spp juga dapat dikendalikan dengan menggunakan insektisida nabati. Tanaman nimba (Azadirachta indica), serai wangi (Andropogon nardus), tembakau (Nicotiana tababacum), mindi (Melia azedarach) (Suryaningsih \& Hadisoeganda, 2004).

Beberapa jenis insektisida nabati yang dapat digunakan untuk mengendalikan Liriomyza spp pada bawang merah adalah Agonal 866 atau Nisela 866, Tigonal 866 atau Kisela 866, Phronal 966, dan Bisela 866 (Suryaningsih dan Hadisoeganda 2004). Penggunaan perangkap likat kuning dan insektisida nabati lebih efektif menekan serangan Liriomyza spp dibandingkan insektisida sintetis (Nonci, 2010). Penelitian ini bertujuan untuk mengetahui efektivitas berbagai konsentrasi ekstrak daun nimba terhadap intensitas serangan Liriomyza spppada tanaman bawang merah lembah Palu.

\section{Metode Penelitian}

Penelitian dilaksanakan di Desa Guntarano Kecamatan Tanantovea Kabupaten Donggala. Lokasi berjarak $13 \mathrm{~km}$ arah Utara Kota Palu. Penelitian dilaksanakan mulai bulan Februari hingga April 2016. Penelitian ini menggunakan Rancangan Acak Kelompok (RAK) yang terdiri atas 6 perlakuan sebagai berikut :
e-ISSN : 2621-7236

p-ISSN : 1858-134X

P0 : Kontrol ( tanpa aplikasi ekstrak nimba )

P1 : Ekstrak daun nimba 10 gr /liter;

P2 : Ekstrak daun nimba $20 \mathrm{gr} /$ liter;

P3 Ekstrak daun nimba 30 gr /liter;

P4 : Ekstrak daun nimba 40 gr /liter;

P5 : Ekstrak daun nimba 50 gr /liter.

Setiap Perlakuan terdiri atas 3 ulangan. Sehingga diperoleh 18 unit perlakuan. Penelitian ini dilaksanakan dengan beberapa tahapan sebagai berikut:

\section{a. Tahap Pembuatan Ekstrak Daun Nimba}

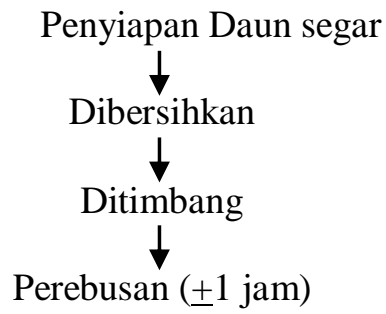

( agar bahan aktif keluar dari daun)

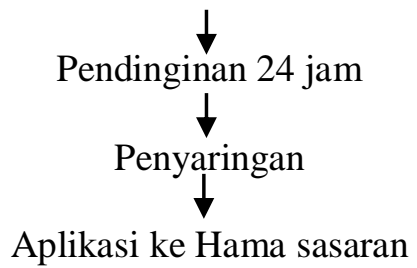

\section{b. Persiapan Lokasi}

Lahan yang digunakan sebagai lokasi penelitian, terlebih dahulu diolah dengan menggunakan bajak dan digaru sebanyak dua kali sedalam $30 \mathrm{~cm}$. Kemudian dibuat petakan berukuran $125 \mathrm{~cm}$ x $400 \mathrm{~cm}$ sebanyak 18 petak. Untuk meratakan permukaan petakan digunakan pacul dan skop. Jarak bedengan perlakuan dalam ulangan adalah $0,5 \mathrm{~m}$, sedangkan jarak petakan antar ulangan adalah 1,0 m. Sebelum dilakukan penanaman terlebih dahulu dilakukan pemberian pupuk kandang 7 hari sebelum tanam sebagai pupuk dasar dengan dosis 10 ton/ha, SP 36200 $\mathrm{kg} / \mathrm{ha}$. Pemberian pupuk Urea, $\mathrm{KCl}$, dan ZA diberikan sebagnyak 2 kali. Tahap satu pada saat tanaman Bawang merah berumur 10 hari setelah tanam dengan dosis $\mathrm{KCl} 100 \mathrm{~kg} / \mathrm{ha}$, urea 100 $\mathrm{kg} / \mathrm{ha}$, Za $200 \mathrm{~kg} / \mathrm{ha}$. Pemupukan Kedua diberikan 30 HST dengan dosis $1 / 2$ dosis urea,dan Za.

\section{c. Penanaman}

Sebelum penanaman, umbi dipotong bagian ujungnya sekitar $1 / 3$ bagian Penanaman dilakukan dengan cara membenamkan umbi dengan posisi umbi tegak lurus pada arah barisan tanaman dalam petak percobaan, dengan jarak 
tanam $15 \times 15 \mathrm{~cm}$. Jumlah populasi bawang sebanyak 100 rumpun per berdengan.

d. Pemeliharaan

Pemeliharaan tanaman meliputi

Penyiangan yang dilakukan pada umur 14 dan 30

HST, sekaligus dilakukan pemupukan susulan dan pembumbunan.

e. Aplikasi Ekstrak Daun Nimba

Perlakuan dilakukan pada umur 14-45

HST dengan konsentrasi perlakuan ekstrak daun nimba yaitu $10 \mathrm{gr} /$ liter air, $20 \mathrm{gr} / \mathrm{liter}, 30 \mathrm{gr} / \mathrm{liter}$, 40 gr/liter dan 50 gr/liter dan dilakukan sebanyak 5 kali dengan interval 7 hari. Aplikasi dilakukan pada sore hari.

f. Parameter Pengamatan

1) Intensitas Serangan

Tanaman yang diamati adalah tanaman sampel yang telah ditentukan dengan cara diagonal sebanyak 10 rumpun tanaman sampel per petak. Pengamatan intensitas serangan Liriomyza spp dengan metode mutlak(Natawigena, 1993).

$$
I=\mathbf{a} / \mathbf{b} \times 100 \%
$$

Keterangan :

I = Intensitas serangan (\%)

a = Banyaknya contoh daun (sampel) yang rusak mutlak ataupun dianggap rusak mutlak.

$\mathrm{b}$ = Banyaknya contoh daun (sampel) yang diamati

2) Produksi

Produksi diamati saat umur 7 hari setelah panen yaitu produksi akhir dari umbi berdasarkan berat kering. Umbi yang ditimbang diambil dari rumpun tanaman pada setiap petak perlakuan.

g. Analisis Data

Untuk mengetahui pengaruh perlakuan, maka dilakukan analisis ragam dan bila berpengaruh nyata dilanjutkan dengan taraf uji BNT $\alpha=0,05$ untuk mengetahui perbedaan antar perlakuan (Sastrosupadi, 1999).

\section{Hasil dan Pembahasan}

\section{a. Hasil}

\section{Intensitas Serangan Liriomyza spp}

Hasil analisis sidik ragam menunjukkan bahwa Intensitas serangan Liriomyza spp pada waktu pengamatan 42 HST dan 49 HST memperlihatkan pengaruh yang nyata, Intensitas serangan Liriomyza spp untuk semua perlakuan dapat dilihat pada Tabel 1, serta Gambar 2 dan 3 berikut ini.
Tabel 1. Rata-rata intensitas serangan Liriomyza spp pada berbagai konsentrasi Ekstrak Daun Nimba yang di uji (setelah ditransformasi ke $\sqrt{x}+0,5)$

\begin{tabular}{|c|c|c|c|c|c|c|c|}
\hline \multirow{3}{*}{ Perlakuan } & \multicolumn{6}{|c|}{ Intensitas Serangan $(\%)$} & \multirow{3}{*}{$\begin{array}{l}\text { Rata- } \\
\text { Rata }\end{array}$} \\
\hline & \multicolumn{6}{|c|}{ Hari Setelah Tanam ( HST ) } & \\
\hline & 21 & 28 & 35 & 42 & 49 & 56 & \\
\hline Kontrol & 1.69 & 3.04 & 4.41 & $6.50 \mathrm{a}$ & $7.02 \mathrm{a}$ & 5.86 & 4.75 \\
\hline 10 gr/liter & 1.66 & 2.53 & 4.12 & $6.23 \mathrm{a}$ & $6.53 \mathrm{a}$ & 6.38 & 4.58 \\
\hline $20 \mathrm{gr} / \mathrm{liter}$ & 1.33 & 2.51 & 3.87 & $4.47 \mathrm{a}$ & $4.65 b$ & 4.07 & 3.48 \\
\hline $30 \mathrm{gr} / \mathrm{liter}$ & 1.79 & 2.95 & 2.7 & $4.12 \mathrm{~b}$ & $4.20 \mathrm{~b}$ & 3.74 & 3.27 \\
\hline $40 \mathrm{gr} / \mathrm{liter}$ & 1.47 & 4.23 & 2.763 & $3.59 \mathrm{~b}$ & $3.59 \mathrm{~b}$ & 3.34 & 3.16 \\
\hline 50 gr/liter & 1.75 & 3.96 & 2.073 & $3.51 \mathrm{~b}$ & $3.51 \mathrm{~b}$ & 3.41 & 3.04 \\
\hline $\begin{array}{c}\text { NP. } \\
\text { BNT(0.05) }\end{array}$ & 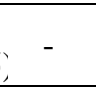 & & & 2.09 & 2,11 & - & \\
\hline
\end{tabular}

Keterangan: Angka yang diikuti huruf yang sama pada kolom yang sama berbeda tidak nyata pada taraf uji BNT 0,05

Serangan Hama Liriomyza spp pada semua petak perlakuan belum nampak pada minggu pertama dan minggu kedua pengamatan (7 HST dan 14 HST) karena ukuran helaian daun masih kecil dan jumlah helaian 2-3 setiap rumpunnya. Memasuki pengamatan minggu ketiga (21 hst), mulai nampak adanya gejala serangan dan meningkat seiring dengan pertumbuhan tanaman. Persentase serangan tertinggi pada 21 hst terlihat pada perlakuan $\mathrm{P} 3(1,79$ persen $)$ dan terendah pada perlakuan $\mathrm{P} 2$ (1,33 persen).

Berdasarkan hasil Uji Beda Nyata Terkecil (Uji BNT) pada taraf uji $(0,05)$ seperti terlihat pada Tabel 1 bahwa pada pengamatan 21 hst, 28 hst dan 35 HST menunjukkan pengaruh yang tidak nyata pada intensitas serangan Liriomyza spp, dengan berbagai perlakuan konsentrasi ekstrak daun nimba yang digunakan dibandingkan dengan perlakuan kontrol (P0), demikian halnya pada pengamatan 56 HST juga tidak menunjukkan pengaruh yang nyata. Namun demikian bahwa pada pengamatan 42 HST perlakuan kontrol (P0) tidak berbeda nyata dengan Perlakuan konsentrasi ekstrak daun nimba 10 gr/liter (P1) dan 20 gr/liter (P2), akan tetapi berbeda nyata dengan perlakuan 30 gr/liter (P3), 40 gr/liter (P4) dan 50 gr/liter (P5). Demikian halnya pada pengamatan 49 HST perlakuan konsentrasi ekstrak daun nimba( P2, P3, P4 dan P5 ) berbeda nyata dengan perlakuan $\mathrm{P} 1$ dan kontrol (P0). 
Jurnal Oagrotech 9 (2) 66-71

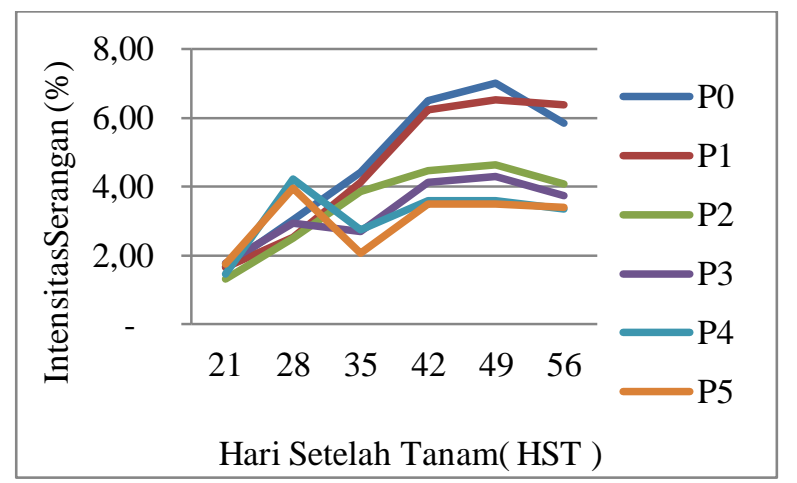

Gambar 2 .Grafik intensitas serangan Liriomyza spp pada berbagai perlakuan konsentrasi ekstrak daun nimba yang diuji

Fluktuasi intensitas serangan Liriomyza spp pada tanaman bawang merah lembah Palu umur 21 HST dan 49 HST cenderung kurvanya bergerak seragam ke atas. Serangan Liriomyza spp sudah mulai nampak sejak pengamatan 21 HST dengan kisaran 1,33 persen sampai 1,79 persen, sedangkan pada pengamatan 49 HST merupakan puncak serangan Liriomyza spp dan terjadi pada semua perlakuan yang diuji dengan kisaran serangan sebesar 4,96 persen sampai 5,72 persen dan mengalami penurunan serangan pada umur 56 hst seiring dengan tanaman bawang merah yang sudah tua dan memasuki masa panen.

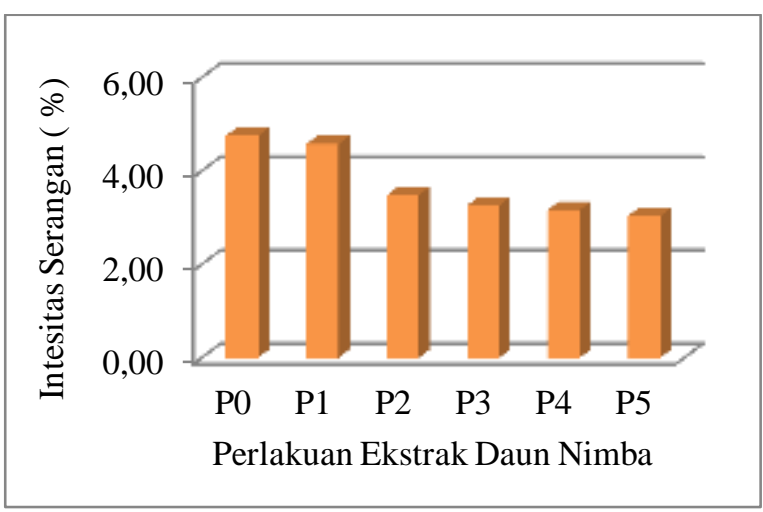

Gambar 3. Grafik Perbandingan Rata Rata intensitas serangan Liriomyza spp dengan perlakuan berbagai konsentrasi ekstrak daun nimba

Grafik pada gambar 3 menunjukkan bahwa terdapat korelasi antara peningkatan konsentrasi ekstrak daun nimba yang digunakan dengan intensitas serangan Liriomyza spp. terlihat bahwa makin tinggi konsentrasi ekstrak daun nimba yang digunakan berimplikasi pada rendahnya intensitas serangan Liriomyza spp.
e-ISSN : 2621-7236

p-ISSN : 1858-134X

\section{Produksi}

Tabel 2. Rata Rata Produksi Bawang Merah Lembah Palu Per Petak Perlakuan

\begin{tabular}{cc}
\hline Perlakuan & Berat Kering Umbi $(\mathrm{kg})$ \\
\hline P0 & 2.10 \\
P1 & 2.43 \\
P2 & 2.73 \\
P3 & 2.57 \\
P4 & 2.90 \\
P5 & 3.20 \\
\hline
\end{tabular}

Berdasarkan Tabel 2 di atas menunjukkan bahwa perlakuan berbagai konsentrasi ekstrak daun nimba tidak berpengaruh nyata terhadap produksi, namun demikian bahwa perlakuan P5 dengan aplikasi ekstrak daun nimba 50 gr/litercenderung memberikan pengaruh produksi yang lebih tinggi dibanding perlakuan lainnya. Produksi bawang yang terserang oleh Liriomyza sppjuga dapat dilihat pada Gambar 4 dibawah ini.

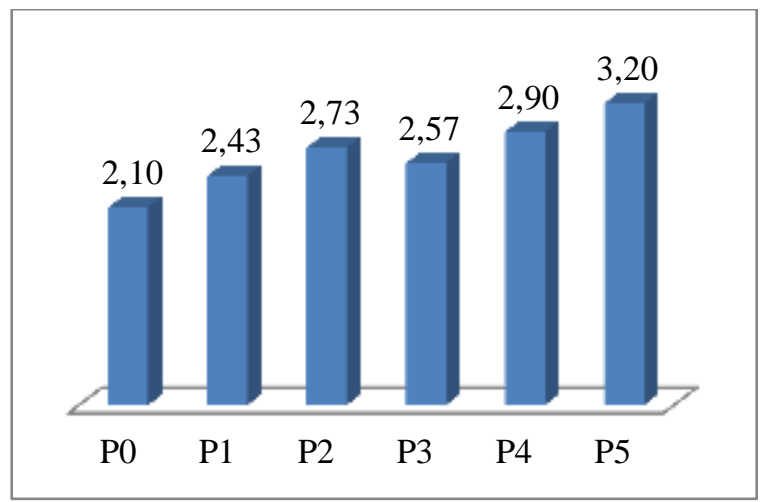

Gambar 4. Rata Rata Produksi Bawang Merah per petak perlakuan $(\mathrm{kg})$

\section{b. Pembahasan}

Hasil analisis sidik ragam menunjukkan tidak berpengaruh nyata antar perlakuan yang diberikan dengan kontrol, pada pengamatan 21 sampai 42 HST. Hal ini diduga karena letak petak antar perlakuan berdekatan dan kemampuan hama lalat untuk berpindah dari satu petak kepetak lainnya sehingga perbedaan yang diberikan saling mempengaruhi (Gellang, dkk., 2009).Hallain diduga efektivitas dari pestisida nabati ekstrak daun nimba yang kerjanya lebih lambat dibanding pestisida kimia. Hal ini sesuai yang dikemukakan oleh Hidayat (2012) bahwa terdapat Kelemahan pestisida nabati yang perlu kita ketahui antara lain: karena bahan nabati kurang stabil mudah terdegradasi oleh pengaruh 
Jurnal Agrotech 9 (2) 66-71

fisik, kimia maupun biotik dari lingkungannya, maka penggunaannya memerlukan frekuensi penggunaan yang lebih banyak dibandingkan pestisida kimiawi sintetik sehingga mengurangi aspek kepraktisannya.

Kebanyakan senyawa organik nabati tidak polar sehingga sukar larut di air karena itu diperlukan bahan pengemulsi.Bahan nabati alami juga terkandung dalam kadar rendah, sehingga untuk mencapai efektivitas yang memadai diperlukan jumlah bahan tumbuhan yang banyak. Hal ini sesuai dengan yang dikemukakan Setyawati dan Rubiati (2008) bahwaekstrak daun nimba mampu mengendalikan sekitar 127 jenis hama dan mampu berperan sebagai insektisida, fungisida bakterisida, antivirus, nematida serta moluksida.

Efektivitas ektrak daun nimba dalam mengendalikan hama, terjadi pada pergantian instar. Nimba tidak membunuh hama secara cepat tetapi berpengaruh terhadap daya makan, pertumbuhan, reproduksi serta berperan sebagai pemandul, mengganggu proses perkawinan, menghambat peletakan telur.

Penggunaan perangkap likat kuning dan insektisida nabati lebih efektif menekan serangan Liriomyza sppdibandingkan insektisida sintetis (Nonci, 2010). Larva Liriomyza sppyang baru keluar, berwarna putih susu atau putih kekuningan,segera mengorok jaringan mesofil daun dan tinggal dalam liang korokan selama hidupnya, hal ini yang menyebabkan penggunaan pestisida terkadang kurang mampu dalam mengendalikan Liriomyza spp (Samsudin et al, 2008).

Intensitas serangan yang tinggi oleh Liriomyza spp. dapat menimbulkan kerusakan yang sangat besar bisa mencapai $60-100 \%$ dan menyebabkan gagal panen Di Sulawesi Tengah, khususnya di Desa Guntarano, serangan Liriomyza spppada tanaman bawang merah umur 1 bulan di Desa Guntarano berkisarantara 22,6-41,4\% (Nonci, 2010).

Berdasarkan hasil penimbangan berat kering menunjukkan bahwa pemberian perlakuan berbagai konsetrasi ekstrak daun nimbapada tanaman bawang merah lembah Palu diduga dapat meningkatkan ketahanan tanaman terhadap serangan hama Liriomyza spp. Hal ini ditunjukkan dengan hasil produksi yang lebih tinggi bila dibandingkan dengan perlakuan tanpa pemberian ekstrak daun nimba. Namun demikian bahwa konsentrasi ekstrak daun nimba tidak begitu berpengaruh terhadap hasil produksi.
e-ISSN : 2621-7236

p-ISSN : 1858-134X

Produksi bawang merah yang dihasilkan belum maksimal. Rendahnya produksi tersebut diduga karena adanya faktor faktor penghambat dalam budidaya tanaman seperti waktu penanaman bawang yang dilaksanakan pada bulan Pebruari sampai April 2016 dimana curah hujan di Daerah Guntarano relatif rendah, serta kondisi tanah di daerah ini yang tidak mampu menahan air dalam waktu lama sesuai dengan kebutuhan pertumbuhan dan perkembangan bawang merah.

Produksi bawang merah yang dihasilkan, seperti diungkapkan diatas menunjukkan bahwa perlakuan yang diaplikasikan cenderung memberikan hasil lebih baik terhadap penurunan intensitas serangan hama Liriomyza spp. Sehingga produksi bawang merah Lembah Palu dapat terselamatkan oleh seranganLiriomyza spp.Peningkatan produksi tidak dapat diartikan karena seringnya aplikasi biopestisida, namun dapat dipahami bahwa produksi akan dicapai maksimal apabila tidak ditemukan adanya gangguan OPT serta menerapkan teknik budidaya sesuai kebutuhan tanaman bawang merah. Menurut Oka (1998) bahwa kehilangan hasil akan terjadi bila tidak dilakukan pengendalian, bisa mencapai $50-75 \%$ dari potensi tanaman tersebut.

Dari hasil penelitian ini memberikan alternatif disamping pengggunaan insektisida yang tidak ramah dengan lingkungan. Keterlanjuran penggunaan pestisida dikalangan petani, hanya dapat diganti dengan teknik pengendalian yang memiliki tingkat efektivitas.yang tinggi. Salah satu upaya tersebut adalah dengan mengendalikan OPT, khususnya Liriomyzas ppada tanaman bawang merah dengan penggunaan ekstrak daun nimba.

Penggunaan pestisida yang berlebihan dan tidak bijaksana tidak hanya menyebabkan polusi lingkungan tetapi juga menyebabkan pengaruh negatif terhadap keseimbangan alam. Hasil kajian oleh Balai Pengkajian Teknologi Pertanian (BPTP) Sulawesi Tengah (2008) bahwa 80 persen petani bawang merah lokal Sulawesi Tengah dalam mengendalikan OPT masih menggunakan racun. Hal ini yang diduga bisa mengakibatkan hama Liriomyza spp berubah status dari hama sekunder menjadi hama utama. Kasus resistensi, resurgensi hama, berkurangnya musuh alami dan munculnya hama baru merupakan pengaruh negatif dari penggunaan pestisida (Untung, 2006). 
Jurnal Agrotech 9 (2) 66-71

\section{Kesimpulan}

Perlakuan ekstrak daun nimba sebesar 50 gr/liter (P5) cenderung memberikan hasil yang lebih baik dengan intensitas serangan Liriomyza spp hanya sebesar 3,04 persen dan produksi umbi sebesar 3,02 kg/petak.

\section{Daftar Pustaka}

Ansar, M., 2012.Pertumbuhan dan Hasil Bawang Merah pada Keragaman Ketinggian Tempat.Disertasi. Program Pascasarjana, Faperta UGM. Yogyakarta.

Anshary, A. dan Shahabuddin, 2010. Liriomyza chinensis (Kato) (Diptera: Agromyzidae) Hama Pendatang Baru Pada Tanaman Bawang Merah di Lembah Palu. Staf Dosen Program Studi Agroteknologi Fakultas Pertanian Universitas Tadulako.

BPTP Sulteng, 2008.Laporan BPTP Sulawesi Tengah. Balai Pengkajian Teknologi Pertanian (BPTP) Sulawesi Tengah.

Diperta Sulteng, 2012. Laporan Budiadaya Bawang Merah Varietas Palu. Dinas Pertanian Propinsi Sulawesi Tengah, Palu.

Data Desa Guntarano, 2015. Laporan Luas Panen Bawang Merah Desa Guntarano. Desa Guntarano, Donggala.

Gellang, A., Anshary, A., dan Shahabudin, 2009. Tingkat Serangan dan Jenis Lalat Penggorok Daun pada Tiga Varietas Lokal Bawang Merah di Lembah Palu, Sulawesi Tengah. Program Studi Agroteknologi Fakultas Pertanian Universitas Tadulako.

Hidayat, R., 2012. Teknik Pengendalian Lalat Buah Bactrocera dorsalis Hend. Dengan Penggunaan Atraktan Alami Tumbuhan Viteks (Viteks negundo L) pada Tanaman Cabai. Untad blogspot.com.

Maskar, Chatijah dan A. Asni. 1999. Pengujian Paket teknologi Budidaya Bawang Merah Varietas Lokal di lahan Kering. Balai Pengkajian Teknologi Pertanian Biromaru T.A. $1998 / 1999$ pp. $25-28$.

Nonci, N 2010, Efektivitas Beberapa Teknik Pengendalian Terhadap Lalat Penggorok Daun ( L.chinensis Kato) pada Bawang Palu. Program Pasca Sarjana Universitas Tadulako, Tesis $65 \mathrm{Hal}$.

Oka, I.N, 1998. Pengantar Pengelolaan Hama Terpadu. Gadja Mada Press. Yogyakarta.
e-ISSN : 2621-7236

p-ISSN : 1858-134X

Shahabuddin, M.Yunus, Hasriyanty, and Y. Tambing., 2015.The role of trap crops for conserving of natural enemies of leafminer on onion in. Scholars Journal of Agriculture and Veterinary Science. 2(5):366-370.

Shahabuddin, M. Yunus, F. Pasaru dan Hasriyanty., 2014. Pengembangan Pengendalian Berkelanjutan Liriomyza chinensis pada Tanaman Bawang Merah di Sulawesi Tengah. Prosiding Seminar Nasional dan Lokakarya FKPTPI, Pokja Wilayah Indonesia Timur, Tanggal 22-23 Mei 2014:73-82.

Shahabuddin, F. Pasaru, \& Hasriyanty, 2013. Pengorok Daun Dan Potensi Parasitoidnya Pada Berbagai Jenis Tanaman Sayuran Di Lembah Palu, Sulawesi Tengah. J. HPT Tropika. 13 (2): 133-140.

Shahabuddin, Anshary A, \& Gellang A. 2012.Tingkat serangan dan jenis lalat pengorok daun pada tiga varietas bawang merah di Sulawesi Tengah.J. HPT Tropika 12(2): 153-161.

Samsudin, Farida, I., Irmawan, D., 2008. Pengendalian Hama Pengorok Daun Liriomyza chinensis (Diptera Agromyzidae) dengan Pendekatan Pertanian Ramah Lingkungan. http://www.pertaniansehat.or.id/cetak.php? $\mathrm{id}=87$.

Suryaningsih, E, dan A.W.W. Hadisoeganda, 2004.Pengendalian Hama dan Penyakit Penting pada Tanaman Cabai dengan Pestisida Biorasional Jurnal Hortikultura 17(3) 261-269.

Setyawati dan Rubiati (2008) Tumbuhan Pestisida Nabati dan Cara Pembuatannya Untuk Pengendalian OPT. Balai Penelitian Sayuran. Pusat Penelitian Pengembangan Hortikultura. Lembang. Bandung

UPT PTPH 2010. Laporan Tahunan. UPT Proteksi Tanaman Pangan dan Hortikultura Dinas Pertanian Sulawesi Tengah Palu.

Untung K., 2006. Pengantar Pengelolaan Hama Terpadu, Gadja Mada University Press Yogyakarta. 